Published by Al-Nahrain College of Medicine P-ISSN 1681-6579

E-ISSN 2224-4719

Email: iraqijms@colmed-alnahrain.edu.iq http://www.colmed-alnahrain.edu.iq http://www.iraqijms.net Iraqi JMS 2018; Vol. 16(1)

\title{
Interleukin-4 Single Nucleotide Polymorphism C-590T Polymorphisms in Relation to Asthma
}

\author{
Ayad M. Gaidan ${ }^{1}$ MSc, Ahmed A. Abbas ${ }^{2}$ PhD, Mohammed A. Hassan ${ }^{3}$ PhD, Hashim M. Hashim ${ }^{4}$ \\ $M R C P$
${ }^{1}$ Dep. Of Biology, College of Science, Tikrit University, Iraq , 2Dept. of Microbiology, College of Medicine, Al-Nahrain University, Baghdad, Iraq, ${ }^{3}$ Dept. of Microbiology, College of Medicine, University of Baghdad, Iraq, ${ }^{4}$ Dept. of Medicine, College of Medicine, Al-Nahrain University, Baghdad, Iraq

\begin{abstract}
Background Single nucleotide polymorphisms in the promoter regions of genes encoding for some interleukins may associate with occurrence of asthma.

Objective To investigate the association of single nucleotide polymorphisms of interleukin-4 (IL-4) (C-590T) and asthma.

Methods Forty-five patients with asthma and 40 apparently healthy subjects (represent the control group) were enrolled in this study. Blood samples were collected from both patients and controls. DNA was extracted from blood samples and gene fragments corresponding to IL-4 C-590T were amplified with specific primers using conventional PCR technique.

Results The heterozygote genotypes of IL-4 C-590T (CT) showed significant association with asthma (OR = $3.922,95 \% \mathrm{Cl}=1.153-13.339, \mathrm{P}=0.028$ ).

Conclusion These results suggest the significance of IL-4 C-590T polymorphism as a risk factor for asthma.

Keywords Asthma, interleukin-4, polymorphism

Citation Gaidan, Abbas AA, Hassan MA, Hashim HM. Interleukin-4 single nucleotide polymorphism C590T polymorphisms in relation to asthma. Iraqi JMS. 2018; Vol. 16(1): 51-56. doi: 10.22578/IJMS.16.1.8
\end{abstract}

List of abbreviations: DNA = deoxyribonucleic acid, $\mathrm{IL}=$ Interleukin, $\mathrm{PCR}=$ Polymerase chain reaction, SNPs = Single nucleotide polymorphisms

\section{Introduction}

The precise causes of asthma are not yet clear, but genetic-environmental interaction is probably responsible for much of the variation in the prevalence rate of this disease. Environmental factors associated with asthma can be easily recognized and avoided. Furthermore, the vast majority of these factors do not exert their effect unless chronic genetic predisposing factors are present ${ }^{(1)}$.
Therefore, investigating the genetic factors associated with asthma could be the cornerstone for defining the most susceptible individuals. Interleukin-4 (IL-4) is one of the most important cytokines in the regulation of allergic response. This cytokine is responsible for immunoglobulin iso-type switching towards immunoglobulin IgE expression (2). Furthermore, it acts as a growth factor for mast cells and is the key signal for the development of Th2 from $\mathrm{CD}+4$ cells ${ }^{(3)}$. All these activities, and may be others, make this cytokine one of the main player in the initiation of asthma. Any genetic alterations that cause an increase in 
the amount and/or activity of IL-4 in expected to affect asthma. Many single nucleotide polymorphisms (SNPs) in the promoter region of this IL-4 gene were found to be associated with different diseases ${ }^{(4,5)}$. Among these SNPs is C-590T, which is associated with higher promoter activity and affects the production of IL-4 (6).

This study aimed to assess the impact of different variants of IL-4 C-590T on the susceptibility to asthma in a sample of Iraqi patients.

\section{Methods}

A total of 45 patients with asthma (age range $16-48$ years, mean $=34.61 \pm 4.11$ years, 18 males and 27 females) who were attending $\mathrm{Al}$ Zahra'a Consultative Centre for Allergy and Asthma and the Consultative Clinic for Chest and Radiology during the period from January to April, 2015 were enrolled in this study. In addition, 40 apparently healthy individual age and sex- matched with patients group were included in this study as control group.

\section{Blood Samples, DNA Extraction and Gene Amplification}

From each subject, $5 \mathrm{ml}$ of blood was drawn from vein puncture in an EDTA tube. DNA was extracted from these samples using ready kit (ZymoBead $^{\mathrm{TM}}$ Genomic DNA Kit, USA). For polymerase chain reaction (PCR) amplification of IL-4 gene, the primer set was forward primer: 5'-TAAACTTGGGAGAACATGGT-3' and reverse primer 5'-TGGGGAAAGATAGAGTAATA$3^{\prime}$ with 195 bp fragment length amplicon.

\section{PCR protocol}

An initial denaturation at $95{ }^{\circ} \mathrm{C}$ for $5 \mathrm{~min}$ followed by 35 cycles of $95{ }^{\circ} \mathrm{C}$ for $50 \mathrm{sec}, 53^{\circ} \mathrm{C}$ for $50 \mathrm{sec}$ and $72{ }^{\circ} \mathrm{C}$ for $1 \mathrm{~min}$. The final extension was achieved at $72^{\circ} \mathrm{C}$ for $7 \mathrm{~min}$.

PCR products from patients and controls were directly sequenced using Big Dye Terminator method/ Sandor Life Sciences Pvt. Ltd /India. The obtained sequences were aligned with normal sequence from GenBank and examined for the presence of SNPs.

\section{Statistical analysis}

The Statistical Package for the Social sciences (SPSS, version 14) was used for statistical analysis. Continuous variables were expressed as mean \pm standard deviation (SD). Risk association between the genotypes and asthma susceptibility was estimated by the calculation the adjusted odds ratio (OR) and 95\% confidence intervals (Cl) using binary logistic regression. Chi square was used for testing the deviation from Hardy-Weinberg equilibrium as well as for comparing between categorical variables. A p-value $<0.05$ was considered statistically significant.

\section{Results}

Table 1 shows the demographic data of the study population. The only demographic factor, which had significant association with asthma is family history. Among asthma patients there was $48.89 \%$ who had one or more first relative with asthma compared to only 5\% among controls who had such relative $(P<0.001)$.

\section{Genotyping}

Gel electrophoresis of PCR product for IL-4 genes are shown in figure 1.

IL-4 C-590T polymorphism appeared in three genotypes which were CC, CT and TT (figure 2). The distribution of these genotypes was within Hardy Weinberg Equilibrium. The frequencies of these genotypes in asthma patients were $64.44 \%, 28.89 \%$ and $6.67 \%$, respectively, while they were $87.5 \%, 10 \%$ and $2.5 \%$, respectively among controls with significant difference for the heterozygous genotype (OR=3.922, $95 \% \mathrm{Cl}=1.153-13.339, \mathrm{P}=0.028$ ) as shown in table 2.

At allelic level, asthma patients had more frequent allele $\mathrm{T}$ than controls $(21.11 \%$ vs $7.5 \%)$ with significant difference as shown in table 2 (OR=3.30, $95 \% \mathrm{Cl}=1.246-8.740, \quad \mathrm{P}=$ 0.016). 
Table 1. Demographic data of asthma patients and controls

\begin{tabular}{|c|c|c|c|c|}
\hline \multicolumn{2}{|c|}{ Risk Factors } & $\begin{array}{l}\text { Cases } \\
\mathrm{N}=45\end{array}$ & $\begin{array}{c}\begin{array}{c}\text { Control } \\
\mathrm{N}=40\end{array}\end{array}$ & P-value \\
\hline \multicolumn{2}{|c|}{ Mean age in years (SD) } & $34.61(4.11)$ & $36.68(4.08)$ & 0.229 \\
\hline \multirow{2}{*}{ Family history } & No & $23(51.11 \%)$ & $38(95.0 \%)$ & \multirow{2}{*}{$<0.001$} \\
\hline & Yes & $22(48.89 \%)$ & $2(5.0 \%)$ & \\
\hline \multirow{2}{*}{ Sex } & Male & $18(40.0 \%)$ & $18(45.0 \%)$ & \multirow{2}{*}{0.403} \\
\hline & Female & $27(60.0 \%)$ & $22(55.0 \%)$ & \\
\hline \multirow{2}{*}{ Smoking } & Never & $37(82.22 \%)$ & $38(95.0 \%)$ & \multirow{2}{*}{0.090} \\
\hline & Smoker (ex/current) & $8(17.78 \%)$ & $2(5.0 \%)$ & \\
\hline \multirow{2}{*}{ Dwelling } & Urban & $29(64.44 \%)$ & $27(67.5 \%)$ & \multirow{2}{*}{0.082} \\
\hline & Rural & $16(35.56 \%)$ & $13(32.5 \%)$ & \\
\hline
\end{tabular}

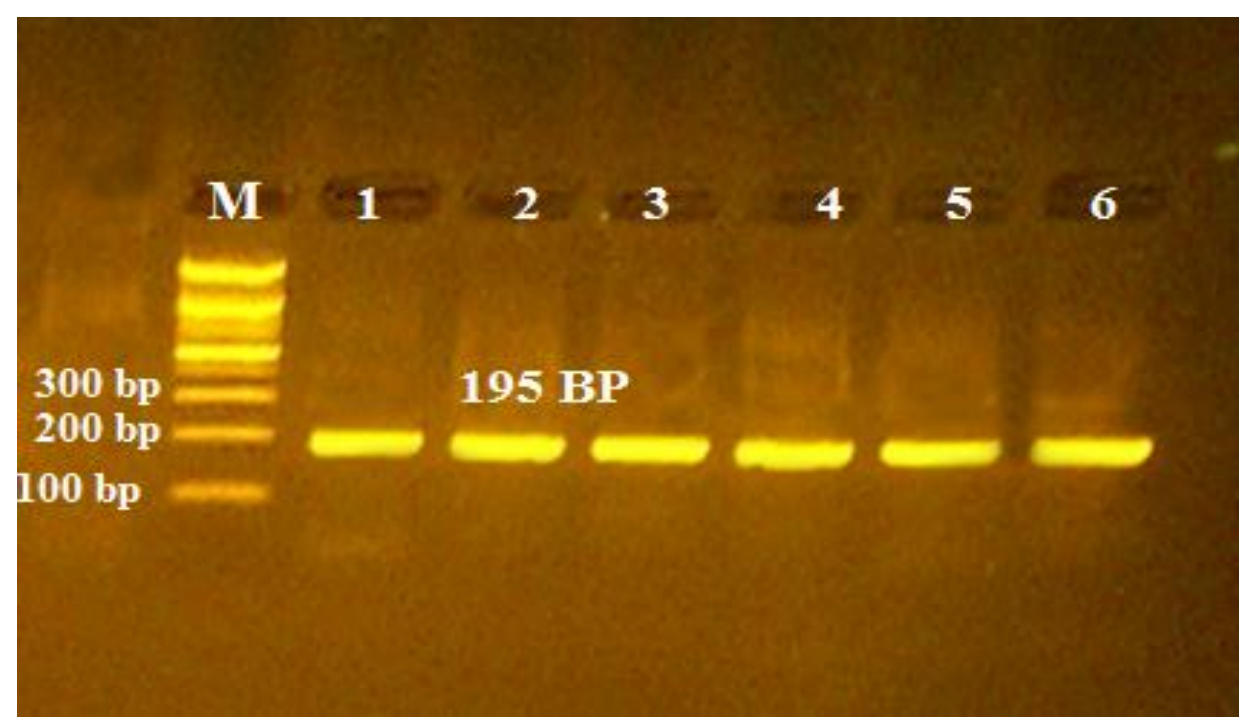

Figure 1. Gel electrophoresis for IL-4 PCR products visualized under UV light after staining with ethidium bromide. M: 100 bp DNA marker; lane 1-6: positive amplification of the gene from DNA extracted from blood samples of asthma patients and controls. The size of PCR product is $195 \mathrm{bp}$

Table 2. Genotypes and allele frequencies of the SNPs C-590T

\begin{tabular}{|c|c|c|c|c|c|}
\hline \multicolumn{2}{|c|}{ Variables } & $\begin{array}{l}\text { Cases } \\
\mathrm{N}=45\end{array}$ & $\begin{array}{c}\text { Control } \\
\mathrm{N}=40\end{array}$ & P-value & OR $(95 \% \mathrm{Cl})$ \\
\hline \multirow{3}{*}{$\begin{array}{c}\text { C-590T } \\
\text { Genotypes }\end{array}$} & $\mathrm{CC}$ & $29(64.44 \%)$ & 35 (87.5\%) & 0.061 & 1.0 \\
\hline & $\mathrm{CT}$ & $13(28.89 \%)$ & $4(10 \%)$ & 0.028 & $3.9(1.153-13.339)$ \\
\hline & $\mathrm{TT}$ & $3(6.67 \%)$ & $1(2.5 \%)$ & 0.276 & $3.6(0.357-36.698)$ \\
\hline \multirow{2}{*}{ Allele } & $\mathrm{C}$ & 71 (78.89\%) & 74 (92.5\%) & \multirow{2}{*}{0.016} & 1.0 \\
\hline & $\mathrm{T}$ & $19(21.11 \%)$ & $6(7.5 \%)$ & & $3.3(1.246-8.740)$ \\
\hline
\end{tabular}




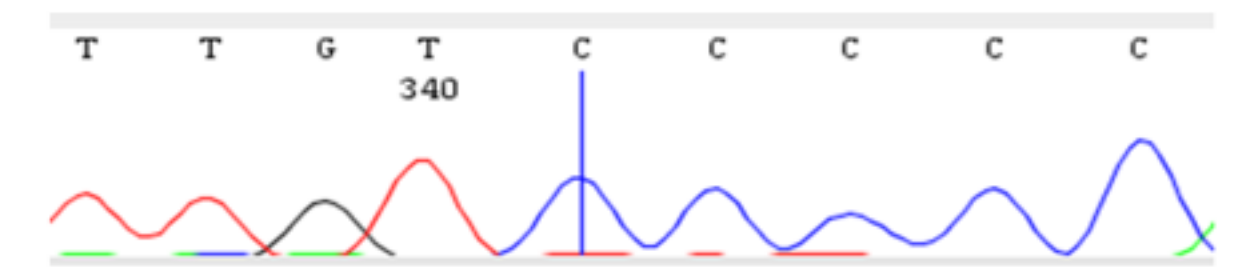

Homozygous wild genotype (CC)

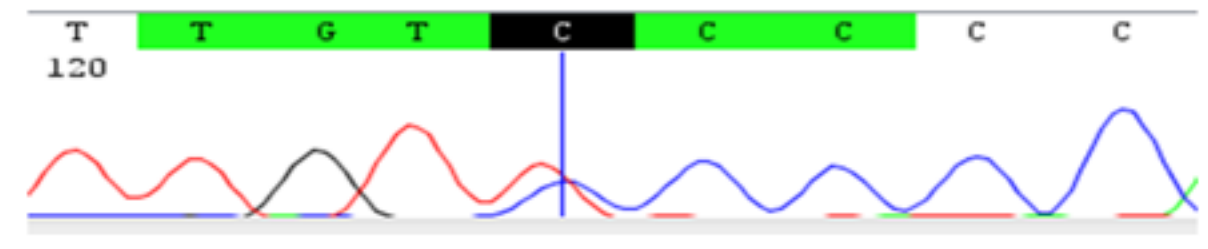

Heterozygous genotype (CT)

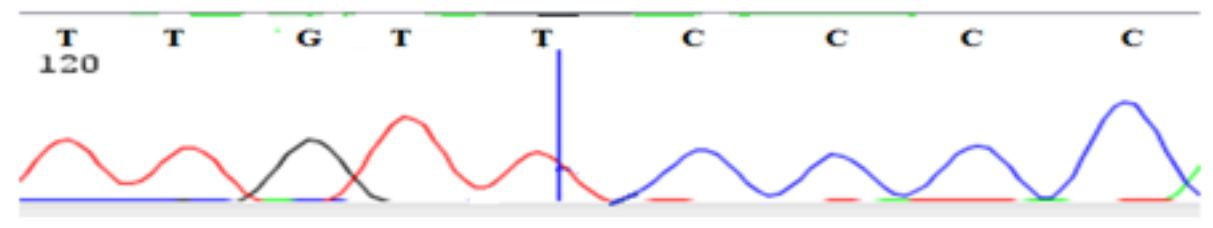

Homozygous mutant genotype (TT)

Figure 2. Different pattern of IL-4 C-590T polymorphism

\section{Discussion}

A significant association between the heterozygote genotype (CT) and the susceptibility to asthma was shown in this study. This implies that CT carriers are at 3.92 folds risk to develop asthma compared to CC carriers. This result was further confirmed at allelic level, where the mutant allele $(T)$ was more frequent among asthma patients than controls with significant difference. Significant association of this SNP with asthma was recorded worldwide such as in Japan (7), Taiwan (8), Algeria (9), Germany (10), west Siberia (2), Macedonia (11), China ${ }^{(12)}$ and Iran ${ }^{(13)}$. However non-significant association was also previously reported in United Kingdom ${ }^{(14)}$, China ${ }^{(15)}$ and Brazil (16). These conflicting results may be related to differences in ethnical and racial origin of the study population. Promoter is a region of DNA where the transcription of a particular gene is initiated. Transcription factors bind to this region and enable RNA polymerase to be situated in an orientation that allows the transcription to begin. Thus, polymorphisms in promoter are expected to influence gene expression although this region is not coding for protein. Interleukin-4 and IL13 are considered as the main factors that regulate allergic response through their effect on isotype switching of immunoglobulin to IgE in B-lymphocyte ${ }^{(17)}$. Furthermore, this cytokine (IL-4) acts as a growth factor for most cells and as a main signal for the differentiation of CD4+ to Th2 ${ }^{(18)}$. All these activities are associated with allergic phenotype. Therefore, it is reasonable to postulate that increased production of this cytokine, for whatever cause, will predispose to allergy. The SNP IL-4 C-590T is located very close to binding site (603 to -588 ) of the nuclear factor of activated T-cells -1 (NFAT-1). This factor is one of the most important factors in IL-4 transcriptions (19). The substitution of cytosine to thymine in the position - 589 was shown to increase the accessibility of NFAT-1 dimer to this site. Thus, more IL-4 is expected to be produced ${ }^{(9)}$. 
Practical studies have supported this hypothesis through the association of $T$ allele with two main phenotypes of asthma with mutant allele $(T)$. The first phenotype is elevated serum levels of IL-4. The second phenotype which a direct result of the first one is the increased serum levels of IgE (14).

On the other hand, there was no statistically significant difference in the frequency of TT genotypes between asthmatic patients and controls in the current study. This may be explained by the relatively small sample size and the possible presence of linkage disequilibrium with other polymorphisms in the same gene. In this regard, Smolnikova et al. reported that this SNP links with other polymorphisms in 3' un-translated region (3'UTR) of IL-4 gene, which may affect the asthma phenotype of the patient ${ }^{(2)}$.

Taken together, these data strongly indicate that allele T of IL-4 C-590Tpolymorphism could be considered as risk factors for asthma in Iraqi patients.

\section{Acknowledgments}

The authors sincerely thank the patients for participating in this work.

\section{Authors Contribution:}

Gaidan: sample collection processing and working. Dr. Abbas: Design of the work, data interpretation, drafting and critical revision of the article. Dr. Hassan: Sample processing. Dr. Hashim: Samples collection.

\section{Conflict of interest}

The authors declare no conflict of interest.

\section{Funding}

No founding was for this research.

\section{References}

1. Subbaroa P, Mandhand PJ, Sears MR. Asthma: epidemiology, etiology and risk factors. CMAJ. 2009; 181(9): E181-E190. doi: 10.1503/cmaj.080612.

2. Smolnikova MV, Smirnova SV, Freidin MB, et al. Immunological parameters and gene polymorphisms (C-590T IL4, C-597A IL10) in severe bronchial asthma in children from the Krasnoyarsk region, West
Siberia. Int J Circumpolar Health. 2013; 72: 10.3402/ijch.v72i0.21159.

3. Hosoyama T, Aslam MI, Abraham J, et al. IL-4R Drives dedifferentiation, mitogenesis, and metastasis in rhabdomyosarcoma. Clin Cancer Res. 2011; 17(9): 2757-66. doi: 10.1158/1078-0432.CCR-10-3445.

4. Wu Z, Qin W, Zeng J, et al. Association between IL-4 polymorphisms and risk of liver disease. Med(Baltimore). 2015; 94(35): e1435. doi: 10.1097/MD.0000000000001435.

5. Fang $X$, Zhu Z, Yang S, et al. Association of IL-4 and IL4 receptor gene polymorphisms with the risk, immunotherapeutic effects and prognosis of advanced renal cell carcinoma. Int J Clin Exp Med. 2016; 9(6):11449-57.

6. Shang H, Cao ZL, Wan YJ, et al. IL-4 gene polymorphism may contribute to an increased risk of atopic dermatitis in children. Dis Markers. 2016; 2016: ID 1021942. doi. Org/10.1155/2016/1021942.

7. Noguchi E, Nukaga-Nishio $Y$, Jian Z, et al. Haplotypes of the 5 'region of the IL-4 gene and SNPs in the inter gene sequence between the IL- 4 and IL-13 genes are associated with atopic asthma. Hum Immunol 2001; 62(11): 1251-7.

8. Chiang $\mathrm{CH}$, Tang $\mathrm{YC}$, Lin $\mathrm{MW}$, et al. Association between the IL-4 promoter polymorphisms and asthma or severity of hyperresponsiveness in Taiwanese. Respirology. 2007; 12(1): 42-8. doi:10.1111/j.1440-1843.2006.00960.x.

9. Dahmani DI, Sifi K, Salem I, et al. The C-589T IL-4 single nucleotide polymorphism as a genetic factor for atopic asthma, eczema and allergic rhinitis in an eastern Algerian population. Int J Pharm Sci Rev Res. 2016; 37(1): 213-23.

10. Woitsch B, Carr D, Stachel D, et al. Comprehensive Analysis of Interleukin-4 Receptor Polymorphisms and Their Association with Atopy and IgE Regulation in Childhood. Int Arch Allergy Immunol. 2004; 135(4): 319-24. doi.org/10.1159/000082326.

11. Trajkov D, Mirkovska-Stojkovikj J, Arsov T, et al. Association of cytokine gene polymorphisms with bronchial asthma in Macedonians. Iran J Allergy Asthma Immunol. 2008; 7(3): 143-56. doi: 07.03/ijaai.143156.

12. Zhang JH, Zhou GH, Wei TT, et al. Association between the interleukin 4 gene $-590 \mathrm{C}>\mathrm{T}$ promoter polymorphism and asthma in Xinjiang Uighur children. Genet Mol Res. 2016; 15(3). doi: 10.4238/gmr.15038363.

13. Kamali-Sarvestani E, Ghayomi MA, Nekoee A. Association of TNF-alpha $-308 \mathrm{G} / \mathrm{A}$ and IL-4 -589 C/T gene promoter polymorphisms with asthma susceptibility in the south of Iran. J Investig Allergol Clin Immunol. 2007; 17(6): 361-6.

14. Walley AJ, Cookson WO. Investigation of an interleukin-4 promoter polymorphism for associations with asthma and atopy. J Med Genet. 1996; 33(8): 689-92.

15. Cui T, Wu J, Pan S, Xie J. Polymorphisms in the IL-4 and IL-4R [alpha] genes and allergic asthma. Clin 
Chem Lab Med. 2003; 41(7): 888-92. doi: 10.1515/CCLM.2003.134.

16. de Faria IC, de Faria EJ, Toro AA, et al. Association of TGF-1, CD14, IL-4, IL-4R and ADAM33 gene polymorphisms with asthma severity in children and adolescents. J Pediatr (Rio J). 2008; 84(3): 203-10. doi: $10.2223 / J P E D .1783$.

17. Laitinen $T$, Kauppi $P$, Ignatius J, et al. Genetic control of serum IgE levels and asthma: linkage and linkage disequilibrium studies in an isolated population. Hum Mol Genet. 1997; 6(12): 2069-76.
18. Paul WE, Seder RA. Lymphocyte response and cytokines. Cell. 1994; 76(2): 241-51.

19. Li-Weber M, Krammer PH, Regulation of IL4 gene expression by $\mathrm{T}$ cells and therapeutic perspectives, Nat Rev Immunol. 2003I 3(7): 534-43. doi: $10.1038 /$ nri1128.

Correspondence to Ayad M. Gaidan

E-mail: ayad.muqdad@yahoo.com

Received Apr. $3^{\text {rd }} 2017$

Accepted Aug. 16 2017 